\title{
Vocal Class in Method Lecture During the Covid-19 Pandemic
}

\author{
Budi Dharmawanputra $^{1 *}$, Heri Murbiyantoro ${ }^{1}$, Harpang Y. Karyawanto ${ }^{1}$ \\ ${ }^{I}$ Faculty of Languages and Arts, Universitas Negeri Surabaya,Indonesia \\ "Corresponding author: budidharmawanputra@unesa.ac.id
}

\begin{abstract}
The Covid-19 pandemic has affected on Vocal Class in Method lecture in the Music Study Program, Sendratasik (Drama, Dance, and Music) Department, Faculty Language and Arts (FBS), Universitas Negeri Surabaya (UNESA). Changing the lectures system from face to face meetings to an online system raises its own problems. Therefore, the aims of this research are to describe the lecture process, learning outcomes, and students responses to the implementation of Vocal Class in Method Lecture. The data collection techniques were carried out by observation, documentation, and a questionnaire. The Method Lecture in the Vocal Class during the Covid-19 pandemic was carried out by combining synchronous and asynchronous approaches. The synchronous approach relies on the WhatsApp chat application and Zoom video conference. Meanwhile, the asynchronous approach via e-mail and the Google Classroom platform. The results achieved from this lecture did not meet expectations, because basically the lecture was not designed for an online system. The assessment was carried out by observing the results of the assignment in the form of a video recording of training and performance. Furthermore, the external constraints in the implementation of lectures indicated that the number of complaints about the unpreparedness of the lecture hardware media, the quality of various internet networks, and the burden of internet quota fees. Meanwhile, internal constraints included students' psychological unpreparedness and student discipline.
\end{abstract}

Keywords: vocal class method, lecture process, learning outcome, students' response

\section{INTRODUCTION}

Corona Virus Disease 2019 (Covid-19), which emerged at the end of 2019 in China, eventually become a pandemic hit the world in early 2020. Indonesia is one of the countries affected by the Covid-19 pandemic. It was known that the Covid-19 case first appeared in Indonesia on February 2020. However, it was only officially announced by the president on March 2, 2020 at the State Palace. On April 13, 2020, through Presidential Decree No.12 of 2020 concerning the Determination of Non-Natural Disaster for the Spread of Corona Virus Disease 2019 (Covid-19), the president declared that the non-natural disaster caused by the spread of Covid-19 was a national disaster. This situation has an impact in various fields of life, including education. Consequently, educational institutions from elementary to tertiary level in Indonesia are forced to change the conventional learning system to an online system. It is because the educational institutions follow the government's appeal to prevent the spread of a wider outbreak.

On March 14, 2020, the Chancellor of UNESA issued a Rector Circular Number B / 15254 / UN38 /
TU.00.02 / 2020 concerning Prevention Measures for the Spread of Corona Virus Disease (Covid-19) at Surabaya State University. Through this letter, the Chancellor stipulated a number of preventive measures governing the activities of various activities of the academic community, including lectures. Therefore, after the letter was issued, lectures are required in online learning.

However, the implementation of online lectures that was not properly prepared brought its own polemic. Lectures that are designed not to use an online system ultimately have to adapt to current situation. It is also experienced by Vocal Class in method lecture during the Covid-19 pandemic at the Music Study Program, Sendratasik Department, FBS, UNESA. Based on these phenomena and facts, the present research interest to uncovering problems that arise in the implementation of Method lectures in Vocal Class in the Music Study Program Sendratasik Department, FBS UNESA due to the Covid-19 pandemic.

Previous research that is relevant to this research is research conducted by Sulasmono [1] with the title "Increasing Vocal Ability through the Solfegio Method". The results of this study indicated that the application of 
the solfegio method could improve the vocal abilities of students. It was also influenced by the good response of students to intonation, rhythm, and harmony exercises. Increased learning activities which include visual activities, listening activities, oral activities and motor activities (observing, paying attention, reading, listening, listening, seeing, saying, reciting, practicing / practicing, expressing, thinking, writing, and making summaries). In other words, giving exercises using the solfegio method could provide a pleasant stimulus so that the learning experience changes [1].

Furthermore, another study was conducted by Utomo and Suharto [2] entitled "Increasing Song Mastery with Ear Training Methods in Vocal Class Learning". The results of this study indicated that learning with the ear training method can improve song mastery. Learning activities, where students listen to their friends while singing and then imitate themselves. It proved that the activity could help students easier to increase their vocal abilities and musical abilities [2].

Regarding the results of previous researches above are relevant to this research, those research focused on the field of vocal learning. However, each research subject has different levels. Research conducted by Sulasmono, [1], and Utomo and Suharto [2], the research subjects were junior high and elementary school students. While the present research would be conducted in the level of higher education. Another thing that distinguishes the present research from the two previous research was the type of the research. The research of Sulasmono [1], and Utomo and Suharto [2] was a type of classroom action research, while this research belongs to the type of qualitative research. Previous research was carried out in normal or face-toface learning situations in the classroom. Meanwhile, this research was conducted when the Covid-19 pandemic situation occurred, so that learning was carried out online through the internet network. Lecturers and students do not meet directly in class.

Based on relevant phenomena and previous researches, in general, the purpose of this research is to evaluate the implementation of the Vocal Class in Method Lecture during the Covid-19 pandemic. Furthermore, this research specifically has the following objectives: (1) to describe the lecture process of the Vocal Class in Method Lecture during the Covid-19 pandemic in the Music Arts Study Program, Sendratasik Departmen, FBS UNESA; (2) to describe the learning outcomes in the Vocal Class in Method Lectures during the Covid-19 pandemic in the Music Arts Study Program, Sendratasik Departmen, FBS UNESA; (3) to describe students responses to the implementation of the Vocal Class in Method Lecture during the Covid-19 pandemic at Music Arts Study Program in UNESA.

The theoretical benefit of this research is that it could provide a repertoire of knowledge and insight on how to conduct Vocal Class lecture Method adapted to the
Covid-19 pandemic emergency situation. Therefore, it is hoped that it could be useful for various related parties who will later be able to develop this research as a scientific research material that can be absorbed by the community and the academic environment. In addition, it is hoped that it becomes the basis for further research.

The practical benefits of the results of this research is it could be used as material for evaluating the implementation of the Vocal Class lecture Method during the Covid-19 pandemic. For this reason, reflection arises in order to improve the quality of the lecture. This research is expected to be able to invite the participation of students and lecturers in developing online lectures in the Music Study Program, Sendratasik Departmen, FBS UNESA as a solution in a pandemic period.

\section{METHODS}

This research used descriptive qualitative approach that focused on the problems faced in lecturing the Vocal Class Method during the Covid-19 pandemic in the Music Study Program, Sendratasik Department, FBS UNESA. The problems that would be addressed include the lecture process, learning outcomes, and students' responses to the implementation of the Vocal Class Method lectures during the Covid-19 pandemic. Data collection techniques were carried out through observation, questionnaires, and documentation. Observations were made online during the semester lecture period, from March to May 2020. The questionnaire was given to all students taking the Vocal Class Method Course. Documentation was obtained from the results of students assignments in the form of assessment sheets and video recordings of exercises and exam performances. Data analysis includes the stages of data collection, data reduction, data presentation, and drawing conclusions. The validity of the data was obtained through technical triangulation and time triangulation.

\section{RESULTS AND DISCUSSION}

\subsection{The Method Lecture Process of the Vocal Class during the Covid-19 Pandemic}

The learning experience that would be obtained in the Vocal Class in Method lectures was the understanding and application of vocal technique learning methods including breathing techniques, intonation, articulation, presentation (interpretation and expression) using basic level etude and simple songs. There are 4 competencies that will be achieved, namely (1) Utilizing learning resources and ICT (Information and Communication Technology) to support the design and implementation of Vocal Class Method learning 
which includes: vocal technique references / literature, various websites related to vocal technique; (2) Having knowledge of vocal techniques, skills in identifying and studying vocal techniques comprehensively; (3) Presenting the repertoire / song pieces according to the concept of the presentation form as a form of implementing a comprehensive vocal technique mastery; (4) Having an ethical, aesthetic, communicative, expressive, appreciative, independent and cooperative attitude in the essence of learning the Vocal Class Method.

The Vocal Class in Method Lecture was held in the even semester of 2019/2020, to be precise the first week of February 2020. The lecture contract was carried out for 15 weeks with a face-to-face system directly in class. Basically the lecture system of this course is designed to be face-to-face. At that time, the Indonesian government had not declared Covid-19 a national disaster.

Entering the 2nd week of March 2020 lectures had been running 6 times face to face and the pandemic situation was increasingly not conducive. Finally, the government appealed to the public to work and learn from home. Therefore, starting from the 7th to 15th meeting, UNESA requires that lecture activities be carried out online. This automatically applied to the Vocal Class in Method Lecture in the Music Arts Study Program, Sendratasik Department, FBS UNESA.

Although one of the competencies that would be achieved was to use information communication technology in learning but the learning design was limited to obtaining references. Therefore, facing the Covid-19 pandemic situation, it is inevitable that the conventional lecture system is changed to an online system as a solution. Judging from the paradigm theory put forward by Thomas Kuhn [3], the facts of this situation can be analogized as a paradigm revolution. Kuhn [3] explained that a paradigm is a point of view, values, methods, basic principles or solving a problem that is adopted by a scientific community in a certain manner [3]. Conventional learning that has been going on is a normal stage of science from the old paradigm. Meanwhile, the current situation in the world of education is faced with a crisis that requires solutions. Attitude to these conditions requires a fast and precise solution by revolutionizing into a new paradigm, namely online learning.

The 7th and 8th meeting lecturers and students tried to adapt to the situation. Lecture materials were still guided by the lecture modules that have been given. However, lecturers provided instruction and lecture administration through the WhatsApp (WA) Group chat application. As for assignment collection, students send via e-mail and Google drive. During that time, the lecturer who taught the course also tried to find other ways by using other applications or platforms that are more effective and efficient. Afterward, entering the 9th meeting the lecturers decided to use the Google
Classroom platform. This was something new for both lecturers and students.

Characteristics of the Vocal Class in Method Lecture in normal situations, the activities were mostly practicing vocal technique learning methods. The theory given was applicative. The tasks were given about the application of vocal technique theory using practice materials and simple songs. Due to the situation that does not allow face-to-face meetings in class, the lecturer assigned students the task which they have to record the results of their training process in each session. Initially this caused a problem that was the unequal size of the video files sent. This was due to the lecturer negligence in providing instructions on assignment delivery criteria. In addition, there were also some students who did not understand the technicalities of processing files so that the upload process was more effective. After this case, there was a conditioning effort by giving directions about the maximum file size limit. The flexibility of the maximum deadline for submitting assignments becomes a consideration that was a maximum of 1 week after the assignment is given.

This lecture applied a learning method with an inquiry approach. Students identified problems that arise in the learning process. Students were required to be more active in the discovery process, learn more on their own and develop activeness in solving problems. Lecture material in the form of etude exercises and simple songs were learned and done by reading scores first. Students were given the freedom to find effective ways to solve their problems. However, before that, basic insights were given about the notation reading method, namely absolute, transposition, and vocalization.

The 9th to 15th meeting of lecturers did not provide online lectures synchronously like video conferencing, but chose chat via the WA Group in real time. This was chosen because there were several students who were constrained by problems with data package costs, gadget readiness, and different network quality. In addition, lecturers also provided opportunities for students to consult during working hours if the actual duration of lecture hours was insufficient. In terms of evaluation and feedback, lecturers provided suggestions and comments on assignments that had been submitted by students via Google Classroom.

\subsection{Learning Outcomes in Vocal Class in Methods Lecture During the Covid-19 Pandemic}

Learning outcomes in the context of this research are a matter of achievement or what is obtained from the Vocal Class in Method Lecture process. Learning outcomes according to Hamalik [4] are patterns of actions, values, knowledge, attitudes, appreciation, abilities and skills [4]. Based on this understanding, 
learning outcomes are a reflection of competency achievement as a learning objective. The following is the percentage value of learning outcomes in the Vocal Class in Method Subject.

There were 55 students who took the Vocal Class in Method lecture. Students who got a final grade of A were $23.64 \%$ or 13 students; final grade A- as much as $30.90 \%$ or 17 students; the final score of $\mathrm{B}+$ is $16.37 \%$ or 9 students; B grade of $12.73 \%$ or 7 students; Bgrades were $7.28 \%$ or 4 students, and $\mathrm{C}+$ scores were $3.63 \%$ or 2 students. Meanwhile, as many as $5.45 \%$ were declared incomplete with an E value because they did not meet the requirements regarding the percentage of attendance in attending lectures and not doing assignments.

According to Carrol (in Sudjana [5]) there are 5 factors that influence student learning outcomes, namely (1) student talent; (2) the time available to students; (3) the time it takes the teacher to explain the material; (4) teaching quality; (5) student ability [5]. Associated with this opinion, it could be seen that students who took classes have varying levels of musicality. The assessment was carried out with a constructivist and humanist approach. This means that the process is very important in determining the final result. Talent is a good asset, but it is not the only determinant of learning completeness.

\subsection{Student Responses to Lecture Implementation}

In order to obtain data on how students respond to the implementation of the Vocal Class in Method Lecture, it was distributed questionnaire to students at the end of the semester. This questionnaire was also distributed online using Google Forms. The questionnaire contains questions about the implementation of the Vocal Class Method.

Students' opinion about the implementation of the Vocal Class in Method lecture in general, that was as many as $77.8 \%$ stated that the lecture was running smoothly and $22.2 \%$ said it was very smooth. It showed that students were able to adapt to changes from conventional learning systems to online learning systems. Even though when asked about how the ideal lecture system was for the Vocal Class in Method Subject, $77.8 \%$ of students answered that they preferred face-to-face learning in class. The remaining $22.2 \%$ chose a combination face-to-face and also online. This means that students actually did not want full online learning.

Regarding the platform used, if the pandemic does not end soon and online learning is the only solution, students are asked to choose the platform they like and feel the most effective. Most of the students, as many as $77.8 \%$, chose to use a combination of several application platforms. Next $11.1 \%$ chose to use V-Learning UNESA or Vinesa, while $11.1 \%$ chose to use Google Classroom.

Regarding the obstacles in implementing online learning, as many as $66.7 \%$ of students expressed complaints about the quality of the operator / provider signal network. $22.2 \%$ of students experienced data packet constraints. Furthermore, $11.1 \%$ of the obstacles faced varied. These obstacles cause them sometimes not to be able to attend online lectures. Equations

Lecture assignments given by lecturers to students proved relatively not burdensome for students. As many as $77.8 \%$ of students did not mind, while $22.2 \%$ felt overwhelmed by online assignments. Regarding mastery of the material, the notation reading method is absolutely favored by $55.6 \%$ of students. Furthermore, $22.2 \%$ each found it easier to use the transposition and vocalist methods.

\section{CONCLUSION}

Based on the existing data, it can be concluded that the Vocal Class in Method Lectures in the Music Arts Study Program during the Pandemic Period could run smoothly even though at the beginning of the transition there was a technological stutter. The use of multiple platforms or applications can complement the shortcomings of each platform or application. The learning outcomes of the Vocal Class in Method Subject are optimal, the basis of which is based on the principles of constructivist and humanist learning. Students responses to the implementation of lectures could be used as material for evaluating their learning. The main obstacle in implementing online learning is the uneven quality of the internet network, the burden of package fees that must be borne, and the student's own personal discipline factor.

\section{ACKNOWLEDGMENT}

We would like to thanks Dr. Trisakti, M.Si. as Dean of the Faculty of Language and Arts, FBS UNESA for the approval and opportunity given in conducting this research. Then, we are mot forgetting to thanks Dr. Anik Juwariyah, M.Si. as the Head of the Sendratasik Department, FBS UNESA, Moh. Sarjoko, S.Sn., M.Pd. as the Head of the FBS UNESA Music Arts Study Program. Furthermore, many thanks to Dr. Warih Handayaningrum, M.Pd. and Dr. Setyo Yanuartuti, M.Si. as the reviewer of this research. Also, we would like to thank the colleagues of this research team: Drs. Heri Murbiyantoro, M.Pd. and Harpang Yudha Karyawanto, S.Pd., M.Pd. as well as the students. 


\section{REFERENCES}

[1] P. Sulasmono, "Peningkatan Kemampuan Vokal Melalui Metode Solfegio", Harmonia: Journal of Arts Research and Education, vol 13, no. 1, 2013.

[2] P. H. T. Utomo, and S. Suharto, "Meningkatkan Penguasaan Lagu Dengan Metode Ear Training Pada Pembelajaran Kelas Vokal”, Uness, 2017. [Online] Available: https://doi.org/10.31227/osf.io/tfdmh

[3] T. S. Kuhn, and D. Hawkins, "The Structure of Scientific Revolutions", American Journal of Physics, 1963. https://doi.org/10.1119/1.1969660

[4] O. Hamalik, Kurikulum dan Pembelajaran. Jakarta: Sinar Grafika, 2004.

[5] N. Sudjana, Penilaian Hasil Proses Belajar Mengajar, Bandung: PT. Remaja Rosdakarya, 2009. 